\title{
PSEUDO-PRISCILLIAN AND THE GOSPEL OF TRUTH
}

\begin{abstract}
A treatise On the Trinity, once ascribed to Priscillian of Avila, but now more commonly held to be the work of a disciple, quotes the aphorism "the name of the Father is the Son" as an apostolic saying. In fact it appears to be a quotation of the Gospel of Truth, affinities to which are also visible in the teaching of this treatise on the procession of the Word from the Father, the role of the Holy Spirit in this procession, the universal bondage of the human race in oblivion, the revelation of the Father's face to the elect, and the common brotherhood of the elect with Christ. After noting a further affinity between the Gospel of Truth and another Priscillianist writing, the article concludes with some reflections on the use of apocryphal literature in the fourth century by authors whose theology was in most respects orthodox.
\end{abstract}

Priscillian of Avila's place in history as the first Christian to be put to death for heresy is secure. ${ }^{1}$ The content of his teaching is still open to dispute, as in his own time, but we know that he asserted the right to make use of apocryphal literature. ${ }^{2}$ He reminded his persecutors that the saints of old had written numerous texts which, though they have perished, cannot have been unwholesome in doctrine, and constructed a list of antediluvian prophets which is adopted in the Koran. ${ }^{3} \mathrm{He}$ read works attributed to the apostle Thomas, whom he seems to have identified with Jude, since he describes the latter not as the brother of Jesus but as "the twin". ${ }^{4}$ Since he wrote at a time when extracanonical sayings of Jesus were still in circulation even among the orthodox, ${ }^{5}$ we should not be surprised to discover them in his writings or in those of his disciples. A clear instance can be found, though it has so far eluded its editors, in the treatise On the Trinity of the Catholic Faith which is not ascribed to Priscillian himself but is thought to be representative of his school. It is said to be monarchian in tenor, but no author to whom that epithet is commonly applied claims biblical warrant for the saying, "the name of the Father is the Son": 6

Pater ergo in filio, et in spiritu sancto filius, unum nomen omnipotentis est dei; qua vocabuli significatione nihil non se esse testatur, qui nihil non posse se praedicat. Ait enim apostolus: Nomen patris est filius, itemque filii pater. (On the Trinity 357-360).

Thus the Father is in the Son, and the Son in the Holy Spirit. There is one name of the almighty God, by the meaning of which term he testifies that there is nothing that he is not, since he indicates that there is nothing that he cannot do. For the apostle says, the name of the Father is the Son, and likewise that of the Son is the Father.

\footnotetext{
${ }^{1}$ See H. Chadwick, Priscillian of Avila: The Occult and the Charismatic in the Early Church (Oxford: Clarendon Press, 1976), 110-169.

${ }^{2}$ Priscillian, Tractate III, in C. Conti, Priscillian of Avila: the Complete Works (New York: Oxford University Press, 2010), 83-99. See further Chadwick, Priscillian, 24, 94-100 and 109-110.

${ }^{3}$ On Adam, Enoch and Noah see Conti (2010), 82-85).

${ }^{4}$ Tractate III, line 8 at Conti (2010), 82.

${ }^{5}$ For further information see the last section of this paper.

${ }^{6}$ Conti (2010), 232-234.
} 
And a little later: ${ }^{7}$

Quod ergo illud est nomen? Quod aliud, nisi quod apostolus: Nomen patris est filius. Manifestavi, inquit, nomen tuum hominibus. (On the Trinity 374-375).

What then is that name? What else, but what the apostle [says], the name of the Father is the Son. I have made known, he says [John 17.6], thy name to human beings.

The sentiment was above reproach, for Justin Martyr had written that the name of the one who said to Moses "for my name was in him" was Jesus (that is, the Greek form of Joshua), and Irenaeus asseverates that the name of the Son is proper to the Father. ${ }^{8}$ The saying itself, however, has an uncanonical source, though one that is now well-known to students of gnostic literature: ${ }^{9}$

Now the name of the Father is the Son. It is he who first gave a name to the one who came forth from him, who was himself, and he begot him as a son.

And again: ${ }^{10}$

The Son is his name. He did not, therefore, hide it in the thing, but it existed; as for the Son, he alone gave a name. The name, therefore, is that of the Father, as the name of the Father is the Son.

But is this a chance quotation, like the quotation of the final logion on the Gospel of Thomas in the second epistle of Clement ${ }^{11}$ I shall argue in this paper that the treatise On the Trinity appears to have borrowed more than this one conceit from the Gospel of Truth: the evidence suggests indeed that he knew it in its entirety, and made use of it less warily than he ought to have done if he wished to pass for a true son of the church.

\section{Summaries}

\footnotetext{
${ }^{7}$ Conti (2010), 234.

${ }^{8}$ Justin Martyr, Dialogue with Trypho 75 (citing Exodus 23.20-21); Irenaeus, Against Heresies 4.17.6. See further L. Hurtado, "Jesus as God's Name, and Jesus as God's Embodied Name in Justina Martyr", in S. Parvis and P. Foster (eds), Justin Martyr and his Worlds (Minneapolis: Fortress Press, 2007), 128-137.

${ }^{9}$ Gospel of Truth at Nag Hammadi Codices I.3.38.8-10, translated by H.W. Attridge and G.W. Macrae in J.M. Robinson (ed.), The Coptic Gnostic Library, vol. 1 (Leiden: Brill, 2000), 111. On the structure and genre of the text see ibid., 67-76. On the Gospel of Truth as a Valentinian document, see H. Ringgren, "The Gospel of Truth and Valentinian Gnosticism", Studia Theologica 18 (1964), 51-65; R. McL Wilson, "Valentinianism and the Gospel of Truth", in B. Layton (ed.), The Rediscovery of Gnosticism, vol. 1. Valentinian Gnosticism (Leiden: Brill, 1980), 133-145.

${ }^{10}$ Gospel of Truth (NHC I.3) 39.19-26, trans. Attridge and Macrae, 113. See also 40.23-29 at p. 115. Notable discussions of this obscure text include P. Ménard, "Les élucubrations de l'Evangelium Veritatis sur le 'Nom"”, Studia Montis Regii 5 (1962), 185-214; J. Fineman, "Gnosis and the Piety of Metaphor: The Gospel of Truth", in Layton, Rediscovery, vol. 1, 289-318; R. Mortley, "The Name of the Father is the Son' (Gospel of Truth 38)", in R.T. Wallis and J. Bregman (eds), Neoplatonism and Gnosticism (SUNY Press, 1992), 239-252. Mortley's thesis that in its present redaction the text is an answer to Eunomius chimes well with the argument of the present paper.

${ }^{11} 2$ Clement 12.2 I a variant of Gospel of Thomas 105. C. Tuckett, 2 Clement: Introduction, Text and Commentary (Oxford: Oxford University Press, 2012) rightly observes that the context differs, but the likelihood that the author knows this gospel is increased by his quotation of logion 17 (otherwise 1 Corinthians 2.9) at 2Clement 11.
} 
The Gospel of Truth is generally agreed to be a product of the Valentinian school, ${ }^{12}$ perhaps identical with the work of that name denounced by Irenaeus; some are disposed to ascribe it to Valentinus himself, though this is a judgment on its quality rather than a deduction from the weak evidence that remains. ${ }^{13}$ It takes the form of a narrative, hieratic in tone yet not so opaque as the typical Gnostic text. It begins by proclaiming the power of the Logos or Word, who is the thought and mind of the Father, having issued from the pleroma, or divine fullness, to perform the work of redemption for those who were ignorant of the Father (NHC I.3, 16.31-17.4). This mission was necessitated by the fall of the world into oblivion, into a fog of error and ignorance which, as the author assures us, did not come from the Father and has no root in itself (17.5-18.12). When Jesus Christ appeared to put an end to oblivion, error grew angry and nailed him to a tree, where he became the firstfruits of the knowledge of the Father, confounding those who were wise in their own conceit, but glorified by the members of the totality, whom he glorified in turn (18.13-20.14). On the cross he published the edict of the Father, unfolding the living book in which the names of those who are to be saved have been inscribed from eternity (20.15-23.18). The Father's Word goes forth in the totality, first containing then disclosing what was hidden of the Father; in him is revealed the Father's bosom, who is the Holy Spirit (23.19-24.21). Error is shaken, envy and strife are banished, the perfection of unity overcomes the deformity of the world and truth is revealed through the tongue of the Holy Spirit to those who emanate from the Father (24.22-27.6). Manifesting what was hidden of the Father, the Word gives knowledge to the elect, rousing them with the aid of the Spirit from dreams of sin and bloodshed, and bringing them home like lost sheep to the fold (27.7-32.31).

Those who remain moved are the material ones (31.1); the Word, however, fills the void with the fragrance of faith and the warm pleroma of love, so that what was lacking in matter is swallowed up in the fecundity of divine energies, so that those who repent are anointed with the mercy of the Father and panted again in paradise, his place of rest (32.32-36. 38). Each of the Father's words is the work of his one will, to be brought forth in a single revelation by the Word who is also the speech of his mind and the thought in which all things were latent before he made them known. (37.1-14). The unsearchable will of the Father is disclosed by his gift of knowledge to the elect, who come forth from him and return in perfect accordance with his will, for the joy and glory of his name (37.16-38.7). In short, the name of the Father is the Son, for it is the Son who alone has

\footnotetext{
${ }^{12}$ In defence of the application of the term "Valentinian" to a school or tradition, see E. Thomassen, The Spiritual Seed: The Church of the 'Valentinians' (Leiden: Brill, 2008).

${ }^{13}$ On the title see B. Standaert, "'Evangelium Veritatis' et 'veritatis evangelium': La question du titre et les témoins patristiques", Vigiliae Christianae 30 (1976), 138-150.For criticism of the prevailing opinion see C. Markschies, Valentinus Gnosticus. Unterushcungen zur valentinianischen Gnosis mit einem Kommenar zu den Fragmenten Valentins (Tübingen: Mohr Siebeck, 1992), 339-356.
} 
seen him and who is therefore able to manifest the invisible name, but for which the very existence of the Father would remain concealed from us (38.8-39.28). He is the one who does not possess the name on loan, the one brought forth to glorify the sweetness of the Father, the magnitude of the name and the pleroma which is his own place of repose (39.29-41.14). Through him the elect in their turn become pleromas, united by a kiss to the Father's countenance, free from envy, refreshed in the Spirit, exempt from death and corruption - true brethren on whom the Father pours out his love so that they may be children whom he is pleased to call his own (41.15-43.23).

The Priscillianist work On the Trinity of the Catholic Faith is a sober exposition of biblical texts which were commonly held to illustrate the Son's relation to the Father and to the world. The first is Baruch 3.38: "he was seen on earth and lived among human beings"; its sibling in the New Testament is John 4.20: "if you love not the brother whom you see, how can you love the Father whom you do not see?". The author urges that the proof of seeing god is to know that we are sons and brothers of the same father and Son, as we learn from Psalm 21.23 (On the Trinity, lines 1-19). This Son is the one who was in the beginning with God, yet also God, according to John 1.1-2; in order that both may be true, we must distinguish the latent import of the word in the Father's mind from his subsequent utterance of the Word (19-50). This Word, without whom nothing was made, is evidently the wisdom of the Father, and the coda at John 1.4 that "in him was life" implies that the Father and Son share one life in the unity of that Spirit from whose fullness the Son proceeds (51112). The unity of Father and Son is proclaimed even in those texts which appear to imply the subordination of the latter. If he subjects himself to the Father at 1 Corinthians 15.28 , it is after subjecting all things to himself as the God of all; according to John 8.28-29 the Father who sent him is also his companion; if he is in the Father and the Father in him at John 10.38, the two are equal, notwithstanding his saying at John 14.28 that the Father is greater (113-169). One power and one will operates in both: if the Son does nothing but by the Father's will at John 6.38 , it is he who judges the world at John 5.22, and his works express the will as the will dictates the works (170-189). Hence the Son can declare at John 13.31 that as the Son of man is glorified God is glorified in him, at John 14.9 that he who has seen the Son has seen the Father, and at John 8.16 that his testimony to himself is also the testimony of the Father and the Spirit, thus fulfilling the biblical precept which requires the concurrence not only of two witnesses but of three (190-289).

The Spirit is shown by John 14.16 to be a person distinct from the Son, while in the baptismal formula of Matthew 28.19 he is shown to be the one Spirit of the Father and the Son. As the emissary of both (291) he communicates the truth that was embodied in the Son, so that the elect may know the presence of the Father and the Son may say of them at John 16.15, "those whom the Father has are mine" (290-397). Because he has manifested the name of the Father, as he declares 
at John 17,6 , it can be said that the name of the Father is the Son; because he was in the beginning with God, he calls himself the beginning at John $8.25 ;{ }^{14}$ therefore he can proclaim at John 14.6 that he is the one way to the Father, at John 6.46 that he alone has seen the Father and at Matthew 11,27 that non-one knows the Father but the Son and those to whom the Son reveals him (397-475). Although the Father had already made himself known at Exodus 6.2-3 as the God of the patriarchs Abraham, Isaac and Jacob, it is only in the fullness of days that he has been fully revealed and only to those whom he has chosen. The patriarchs walked in the faithful expectation that the vision which was not yet granted to them would be vouchsafed to their posterity; even Moses, when he beheld the back parts of God at Exodus 33.23, was only foreseeing that his descendants would be granted that direct knowledge of God's countenance which was still denied to him (475-630).

It will be obvious from these summaries that the two texts are not alike in form and not always at one in their theological premisses. ${ }^{15}$ The Priscillianist has nothing to say against matter, and it would not be easy to isolate a homoousian Trinity of three persons in the Valentinian text. The Gospel of Truth is thus at most one source of the tract On the Trinity; the tenets which they share, however, are not such as the Priscillianist would have met in other circles, and are therefore all the more likely to betoken his dependence on the Gospel rather than a fortuitous coincidence of ideas.

\section{Particulars}

We cannot make an argument of every similarity. The Priscillianist and the Gospel of Truth agree that the Son is the Word who proceeds from the fullness of the Godhead, that the Father is visible to him alone and manifested in his works, and that each of these works was already conceived by the Father's will before the Son performed it. We also read that where the Son gives glory he is glorified, although this is said of the Father in the Priscillianist and of the elect in the Gospel of Truth. These, however, were universal tenets of orthodoxy in the late fourth century, and therefore afford no proof of the Priscillianist's acquaintance with the Gospel of Truth; on the other hand, if his knowledge of this text can be demonstrated on other grounds, these facts can be cited as further evidence of his sympathy with its contents. And indeed it is not difficult to show that there are statements in On the Trinity which are at odds with the thought its time that we now call "Nicene", but perfectly consonant with the gospel which asserts that "the name of the Father is the Son".

Two stages.

\footnotetext{
${ }^{14}$ An error shared by Augustine, Tractates on John 38.4.

${ }^{15}$ They differ also on predestination. The Gospel of Truth affirms that the elect are those who discover that their names are eternally written in the book of life; the Priscillianist, notwithstanding his four citations of Matthew 11.27 (453-454, 460-461, 520, 525), adds the rider at 529-530 that no-one's ears are so closed that divine speech cannot penetrate them.
} 
According to the Gospel of Truth, the Son was hidden in the depths of the Father before his emergence as the Logos:

When therefore it pleased him that his name which is loved should be his Son, and he gave the name to him, that is, him who came forth from the depths, he spoke about his secret things, knowing that the Father is a being without evil. For that reason he brought him forth in order to speak about the place from which he had come forth, and to glorify the pleroma, the greatness of his name and the sweetness of the Father. (Gospel of Truth (NHC 1.3), 40.24-41.3 at Attridge and Macrae, 114-115).

If the Gospel of Truth is a second-century work, this notion that the Logos existed within the Father before he came forth was a commonplace of the time. ${ }^{16}$ In the late fourth century, however, it was an obsolete tenet, if not a heretical one, which appeared to compromise the eternity of the Son and had not been entertained by any Christian teacher since Marcellus of Ancyra. The Nicene gloss on the word monogenês - "that is, from the essence (ousia) of the Father"- was omitted from the Constantinopolitan Creed of 381, perhaps because it suggested emanation from a state of latency. The Priscillianist, however, seems to be unaware that anyone has impugned this concept of a twofold Logos, initially residing in the Father as thought, then coming forth as speech: ${ }^{17}$

Sequitur enim, Et deus erat verbum. Deum autem sensum scire debemus; vel quod apud deum sensus manebat, cuius habitaculum sensus est, vel quod aliud non possumus deum vocare quam sensum ... Sensus enim in silentio constitutus verbo indiget, similem tantummodo conscientiam futuri apud seipsum forma meditata, verbumque ipsum non aliunde accersitum, sed in praedestinatione cogitationis voluntate formatum. (On the Trinity 32-3 and 38-40).

For there follows, And God was the word [John 1.1c]. "God" we should understand as "thought", either because the thought remained with God, whose abode is thought, or because we cannot call God anything but thought ... For the thought which comes to exist in silence has need of a word, formally meditating within itself the conscious similitude of what is to come; and the word is not summoned from some other place, but formed by the will according to the determination of thought.

The notion that Christ is the word who proceeds from silence is first attested in the letter of Ignatius to the Magnesians, though here (if the text is sound) it signifies his emergence from the womb of Mary to fulfil the hitherto secret plan of God. ${ }^{18}$ In the Valentinian system which was known to heresiologists by the end of the second century, Logos proceeds from the union of Silence and the Father through an intermediate "syzygy" or coupling of mind and truth. ${ }^{19}$ It is possible that a rudimentary form of this myth, hypostatizing terms which in Ignatius had only a figurative import, ${ }^{20}$ is preserved in the Gospel of Truth; in any case, it is clear that the Priscillianist has adopted a position

\footnotetext{
${ }^{16}$ Tatian; Oration 5; Theophilus of Antioch, To Autolycus 2.10; Tertullian, Apology 19 and Against Praxeas 5.

${ }^{17}$ Conti (2010), 214.

${ }^{18}$ Ignatius, Magnesians 8.2. J.B. Lightfoot, Ignatius and Polycarp, vol. 2 (London: Macmillan, 1890), argues that the reading "from silence", rather than the MS "not from silence", should be upheld because it has better external support and is more harmonious with the doctrine of other letters in the corpus. See also W.R. Schoedel, A Commentary on the Letters of Ignatius of Antioch (Minneapolis: Fortress Press, 1985), 120-122. T.D. Barnes, "The Date of Ignatius", Expository Times (2010), 105-118 employs familiar arguments in favour of "not from silence", but does not address the equally familiar counter-arguments.

${ }^{19}$ Irenaeus, Against Heresies 1.1-2.

${ }^{20}$ See M.J. Edwards, "Ignatius and the Second Century: An Answer to R. Hübner", ZAC 2 (1998), 214-225.
} 
which in his day would have been more congenial to the Valentinians than to any other ecclesiastical party, whether Nicene or anti-Nicene.

\section{Primacy of the Spirit}

In the Gospel of Truth the Spirit is the bosom in which the Son reposes before he comes forth. Again, where Truth is said to be the mouth of the Father, the Spirit is his tongue, and hence (we infer) the organ from which the Word proceeds):

The Father reveals his bosom. - Now his bosom is the Holy Spirit. - He reveals what is hidden of him - What is hidden of him is the Son. (Gospel of Truth (NHC 1.3), 24.9-12, at Attridge and Macrae, 92-93).

For, as for everyone who loves the truth - because the truth is the mouth of the Father; his tongue is the Holy Spirit - he who is joined to the truth is joined to the Father's mouth by his tongue, whenever he is to receive the Holy Spirit, since this is the manifestation of the Father, and his revelation to his aeons. (Gospel of Truth (NHC 1.3), 26.33-27.7 at Attridge and Macrae, 96-97).

It was not the usual practice of those teachers whom we call catholic in the fourth century to give the Spirit a role in the generation of the Son; on the contrary, says Athanasius, it is not the Son who receives from the Spirit but the Spirit from him. Gregory of Nyssa credits the Spirit only with the anointing of the Son within the Godhead; ${ }^{21}$ if Marius Victorinus goes so far as to hint that the Spirit is his mother both above and below, ${ }^{22}$ this is a measure of his idiosyncrasy, to which we shall return. The Priscillianist, however, declares that the Word of creation was brought forth by the mouth of the Spirit: ${ }^{23}$

Sensus igitur est verbi vis, qui ipse sibi loquitur; sic et oris et vocis officio impletur. Ecce unitas patris et filii: quae vult ipse sibi loquitur. Audi qui loquitur, quo postquam unus et plenus et verus voluntati suae, meditationi suae formatur, spiritus sancti ore prolatum est verbum. ${ }^{24}$ Opus sequitur, et omnia, quae prius non erant, imperio illius vocitata prosiliunt. (On the Trinity 48-53).

The thought is therefore the force of the word, which \{i.e. the thought\} speaks to itself; hence it is brought to fulness ${ }^{25}$ by the office of both the mouth and the voice. Behold the unity of the Father and Son: to himself he says what he wishes. Hear who it is who speaks, by whom, after he is formed as one and full and true to his own will and meditation, the word is brought forth by the mouth of the Holy Spirit. The work follows, and all those things which did not exist before spring up when summoned by his command.

The Spirit, as we go on to learn, is the mutual life of the Father and Son, the third witness by whom the truth of the divine testimony is established. In this world it is the Son who communicates life to the saints as the gift of the Spirit, but we are never told that the Spirit himself, as opposed to his gift, is the emissary of the Son. Nor is anything said of the procession of the Spirit from the Father, a sine qua non of orthodoxy after 381.

\footnotetext{
${ }^{21}$ Gregory of Nyssa, On the Holy Spirit, in Gregorii Nysseni Opera Omnia III.1, ed. F. Mueller (Leiden: Brill, 1958), 102-103.

${ }^{22}$ Athanasius, Against the Arians 2.1; Marius Victorinus, Against the Arians 1.58, p. 93 Locher.

${ }^{23}$ Conti (20120), 214.

${ }^{24}$ Conti (2010), 214 punctuates as follows: spiritus sancti ore prolatum est, verbum opus sequitur; but it seems to me that prolatum requires a subject.

${ }^{25}$ Conti (2010) 215 has "it performs the duty of both the mouth and the voice"; but impletur is passive.
} 


\section{Oblivion}

The purpose of the Son's mission in the Gospel of Truth is to save the elect from oblivion, the ignorance of the Father, which came into existence because of him though not by his command: ${ }^{26}$

But what comes into existence in him is knowledge, which appeared in order that oblivion might vanish and the Father might be known. Since oblivion came into existence because the Father was not known, then if the Father comes to be known, oblivion will not exist from that moment on.

In the treatise On the Trinity the Latin noun oblivio occurs twice. At 405-415 he argues that unless the disciples had drowned the teacher's memory in "another draught of oblivion" (alio oblivionis poculo), their petition that Christ would show them the Father must indicate that hitherto, as Israelites, they had known the Father in spirit only, not by sight but only by the witness of his prophets. ${ }^{27}$ The word "another" implies that, like the rest of the world, they had been in a state of oblivion before they received this aural testimony. At 545 he infers from Christ's undertaking to reveal himself at a future time to those who had already seen him that "he was fearful of our forgetting him (metuit oblivionem sui nobis), a thing excluded by that perfect charity, for which this prize [i.e. the vision of Christ] is reserved.." ${ }^{28}$ Read in conjunction with its first occurrence at 515 , the word oblivio here denotes a second bondage to the ignorance from which the believer in Christ has been redeemed.

The Face of the Father.

The true elect in the Gospel of Truth are those who have "participated in his [the Father's] face through kisses, that is to say, the ones upon whom the love of the Father has been poured out and in the midst of whom there is no lack of him. ${ }^{29}$ The conceit is borrowed from Matthew 18.10, where it is the angels of little children who behold the face of God and there is no hint of erotic imagery. The Priscillianist contrasts the knowledge of the face of God, which is vouchsafed to the church alone, with the shadowy prescience that Moses enjoyed when, by divine permission, he hid himself in a rock and looked upon the back parts of God $(576 ; 586-595)$. These back parts, says the exegete, were the future mercies of God to the descendants of the patriarchs (580-584); it was God's will, however, that his promises to Abraham and Moses should be made good only after the revelation of the Saviour and that those who lived before this should have only that limited understanding of him that comes through faith (597).

\section{Brotherhood.}

\footnotetext{
${ }^{26}$ Gospel of Truth (NHC 1.3), 18.5-11. Cf.18.18; 21.36-38; 22.36-37 at Attridge and Macrae, 82-87.

${ }^{27}$ Conti (2010), 236. Cf. John 14.8.

${ }^{28}$ Conti (2010), 244. Conti's translation "fear our oblivion" is intended, I believe to convey this sense although his use of the English noun is unidiomatic and he omits to translate the possessive pronoun.

${ }^{29}$ Gospel of Truth (NHC 1.3), 41.34 and 43.7-8: see Attridge and Macrae, 114-117. Cf. Luke 17.20.
} 
The Priscillianist regards the elect not merely as brothers in Christ but as the brothers of Christ himself. Having no warrant in the New Testament for this belief, he turns to the Old: ${ }^{30}$

Adhuc etiam et videntis argumentum est opus manifestum in filio; quod cum deo deum salvatorem nosse primogenitum in multis fratribus apostolo dicit. ${ }^{31}$ ipse in propheta ostendens in se domini personam patris et filii eiusdem et fratres appellat et filios, quia scriptum est: narrabo nomen tuum in fratribus meis, in medio ecclesiae cantabo sibi. Itemque dicit: Ecce ergo et filii, quos mihi dedit deus. Qui fratres eius sunt, qui non ipse filius? (On the Trinity 11-16).

Furthermore, a proof that one sees [i.e. sees God, as at 1 John 4.20] is manifest working in the Son. He says to the apostle that this is to know, together with God, the saviour God, first born among many brethren [Romans 8.29]. He himself, displaying the person of the Lord in himself through the prophet, calls them both brothers and sons of the Father and the same Father's Son, as it is written: I shall tell your name to my brothers, in the midst of the assembly I shall sing to thee [Psalm 21.23]. Again he says, See therefore also the sons whom God has given to me [Isaiah 8.18]. Who can be the brothers of one who is not himself a son?

Nicene authors sometimes hint that the saints are brothers of Christ, ${ }^{32}$ but it is only in Valentinian texts that this is a salient teaching. Perhaps it is not yet so in the Gospel of Truth, for, while the elect are praised in the closing lines as children in whom the Father delights and brothers on whom he pours out his love, ${ }^{33}$ it is possible that they are children to him but brothers to one another. The distinction between the elect and the one true Son is not effaced, as it is only the latter who has not received the name on loan. Nevertheless, the author goes so far as to affirm that the name of the Father rests in all "sons of the name" ${ }^{34}$ In another Valentinian text, the Gospel of Philip, we read that, whereas some have the name on loan, the elect possess it as a gift from the Holy Spirit; ${ }^{35}$ moreover, while the Son is said to be the sole bearer of the ineffable name, the elect have a right to be called his brothers because it is not the Son but only the Father who makes sons:

The father begets a son and the son has not the power to make a son. For he who has been begotten has not the power to beget, but the son gets brothers for himself, not sons. (Gospel of Philip 58.23-26 at Isenberg, 154155).

\footnotetext{
${ }^{30}$ Conti (2010), 212 translates: "In addition, it is necessary that the argument of the one who sees should be evident in the Son; the apostle says that Our God and saviour knew with God that 'he was the firstborn among many brothers', and as a prophet, showing in himself the person of the Lord", etc. But (a) he is taking argumentum as the object of opus, despite the fact that opus (in the sense of "need") takes the more correct ablative in the previous sentence; (b) he has translated apostolo as if it were a nominative; (c) a full stop is necessary after dicit, since otherwise the following clause (built round the verb appellat) will be anacolouthic. ${ }^{31}$ I insert a full stop here; see previous note.

${ }^{32}$ Athanasius, Against the Arians 2.62; Macarius of Egypt, Homily 16.8; John Chrysostom, Homilies on John 46.3.

${ }^{33}$ Gospel of Truth (NHC I.3), 43.5-7, at Attridge and Macrae, 117.

${ }^{34}$ Gospel of Truth (NHC I.3), 38.25-30, at Attidge and Macrae p. 111: "Who, therefore, will be able to utter a name for him, the great name, except him alone to whom the name belongs, and the sons of the name in whom rested the name of the Father".Nevertheless, at 40.9-10 it is the distinction of the Son that he did not receiuve the name on loan.

${ }^{35}$ Gospel of Philip 64.23-29, ed. and trans. W.W. Isenberg, in J.M. Robinson (ed.), The Coptic Gnostic Library, vol. 2 (Leiden: Brill, 2000), 168-169.
} 
One of the many indices of the Valentinian provenance of this text is its proclamation that the name which cannot be uttered is the one name, that of the Father, which has been given to the Son. ${ }^{36}$ Thus the Priscillianist and the Gospel of Philip allude to the same uncanonical saying and use the language of fraternity in the same anomalous manner: we can hardly suppose the two to be unrelated, and the Gospel of Truth is at least part of the common ground between them.

\section{The return}

There is one motif in the Gospel of Truth, the return of the elect through Christ, ${ }^{37}$ which finds an echo not in the work On the Trinity but in a prologue to the Gospels which is also ascribed to a follower of Priscillian: ${ }^{38}$

Cui ideo post baptismum filii dei a perfectione generationis in Christo impletae et repetendae a principio nativitatis humanae potestas permissa est, ut requirentibus demonstraret, in quo adprehendens erat, per Nathan filium introitu recurrentis in deum generationis admisso indispartibilis dei, praedicans in hominibus Christum suum perfecti opus hominis redire in se per filium facere, qui per David patrem venientibus iter praebebat in Christo. (Prologues of the Monarchians 65-71).

To [Luke] authority was given, after the baptism of the Son of $\mathrm{God}^{39}$ [to pass] from the perfection of generation which was fulfilled in Christ to the rehearsal of his human nativity, to the end that he might make clear to inquirers what particular knowledge he had ${ }^{40}$. Making his entrance by way of Nathan the son ${ }^{41}$ into the lineage of the indivisible God as it was carried back to $\mathrm{God}_{1}{ }^{42}$ he proclaimed that Christ, in the midst of humanity, caused the humanity whom his own work had perfected ${ }^{43}$ to return to him by way of the son, who was offering ${ }^{44}$ a way in Christ to those who came through David his father. ${ }^{45}$

The purpose of this tortuous speculation is to explain the postponement of Christ's genealogy in Luke's gospel. The return through Nathan to Christ is a presupposition which is assumed to need no defence, and which must therefore have been regarded by the author as a postulate of orthodoxy, at least in the circles to which he addressed this tract.

\section{Conclusions}

\footnotetext{
${ }^{36}$.Gospel of Philip 54.6-11 at Isenberg, 148-149.

${ }^{37}$ See e.g. 35.23-24 at Attridge and Macrae, 107: "For the bringing back is called repentance". Again at 37.3638.4 at 111: "this is the Father, from whom the beginning came forth, to whom all will return who have come forth from him".

${ }^{38}$ Conti (2010), 254.

${ }^{39}$ Luke 3.21.

${ }^{40}$ For this interpretation of in quo adprehendens erat, cf. p. 252 line 20 Conti: in quo adprehensi sunt et adprehendere expetunt. Cf. Chadwick, Priscillian, 107, who compares Priscillian, Tractate 11.9-11.

${ }^{41}$ Luke 3.31. Conti, 255 has "son of Nathan", but this construction, while grammatically possible, obscures the parallel between Nathan and his father David. For the same reason, I cannot follow him in taking "son" in the following clause to mean the Son of God. Again cf. Chadwick, Priscillian, 107, though I cannot see how he attaches the possessive pronoun suum to indispartibilis dei.

${ }^{42}$ Luke 3.38. Cf. Origen, Homilies on Numbers 27.3, p. 260 in the edition of W. Baehrens (Leipzig: Hinrichs, 1921).

${ }^{43}$ Literally "his own work of the perfect human". Cf. Ephesians 4.9.

${ }^{44}$ The subject of praebebat could be the evangelist, Christ or Nathan; but if it is Luke, the claim that he offered the way is obscure, and if the subject is Christ the words in Christo will be redundant.

${ }^{45}$ Meaning perhaps those who had a proleptic knowledge of Christ through the Psalms.
} 
These observations surely suffice to prove that the Gospel of Truth was known to the Priscillianist, and was therefore current in Latin at a later date than has hitherto been suspected. No comparable evidence can be adduced in favour of Henry Chadwick's suggestion that the author was quoting a portion of the apocryphal Acts of John which is no longer extant. ${ }^{46}$ This is not to say that author can be convicted of the "heretical" or "sectarian" tendencies which, as Virginia Burrus observes, have been imputed to the Priscillianists by leading scholars of the twentieth century. ${ }^{47}$ Her own expression, "conflicts of authority" ${ }^{48}$ comes nearer to catching the timbre of a quotation which, although it has no canonical source, asserts only what is stated in other terms by catholic writers of the second century. The citation of one dictum does not prove that the writer ascribes the same authority to the Gospel of Truth that he and others ascribed to the writings of our New Testament. As we have already indicated, unwritten sayings of Jesus were quoted even by the most orthodox: a number of writers who recognised only four canonical gospels urged their readers to "be good money-changers" as though this apocryphal dictum were apostolic or even dominical. ${ }^{49}$ Sometimes orthodox writers appear to have suffered a lapse of memory, or to have granted canonical status to texts that were commonly held in honour but assigned to a second rank. Optatus, for example, cites "thou shalt not make a schism" as though it were found in everyone's bible: ${ }^{50}$ if his source is not the Didache (a version of which was numbered by Rufinus among the "ecclesiastical writings supplementary to the canon") $)^{51}$ it will have been the Epistle of Barnabas, which was appended to the New Testament by the scribe of Codex Sinaiticus. ${ }^{52}$ The historian Gelasius of Cyzicus preserves a fanciful dialogue between a simple man of faith and an Arian philosopher, in which the former cites the Assumption of Moses; ${ }^{53}$ since he puts an objection into the mouth of the philosopher, the author was well aware that this was not a text fit for use in theological disputation.

For all that they lacked authority, these texts were not heretical; an appeal to any of them might be deemed infelicitous, but not illicit. Marius Victorinus is the one author before Priscillian

\footnotetext{
${ }^{46}$ Chadwick, Priscillian, 100-2 (see also p. 24 on Filastrius of Brescia and the apocryphal acts). From the author's usage elsewhere (see Trin. 11-16 and n. 32 above) we may surmise that the apostle to whom he ascribes the saying is Paul; for a similar error by an orthodox writer see the following note.

${ }^{47}$ V. Burrus, The Making of a Heretic: Gender, Authority and the Priscillianist Controversy (Berkeley: University of California Press, 1995), 18-21.

${ }^{48}$ Making of a Heretic, 21, referring favourably to A, Barbero de Aguillera, "El priscilianismo: Herejia o moviemento social?", Cuadernos de historia de España 37-38 (1963), 5-41.

${ }^{49}$ Cyril of Jerusalem, Catechetical Homilies 6.36; Cyril of Alexandria, Commentary on John 5.4, in Patrologia Graeca 73, 651a. Both juxtapose this adage with 1Thessalonians 5.21, and Cyril of Alexandria ascribes it to Paul himself. Perhaps the Priscillianist has been misled by a subconscious recollection of Philippians 2.9.

${ }^{50}$ Against the Donatists 1.21. Cf. ibid. 1.5 and appendix 1.12, with P. Aldridge, "Peter and the "Two Ways", Vigiliae Christianae 53 (1999), 233-264.

${ }^{51}$ Rufinus, De Symbolo Apostolorum 38, C.H. Heurtley, De Fide et Symbolo (Oxford: Parker, 1911), 160.

52 On this fact and its significance see J. Carleton Paget, The Epistle of Barnabas (Tübingen: Mohr Siebeck, 1994), 253-260.

${ }^{53}$ Gelasius, Church History 2.17.17, p. 54.24 in the edition of G.C. Hansen (Berlin: De Gruyter, 2002).
} 
who fell among the Gnostics in his quest for a philosophical formulation of Nicene teaching on the Trinity. The texts on which he drew, the Zostrianus and Allogenes, are now preserved, like the Gospel of Truth, in a miscellaneous hoard of documents, some or all of which may once have belonged to a monastic library of the mid-fourth century. ${ }^{54}$ Victorinus was neither monk nor prelate, and will no doubt have perused these texts in the course of his career as a teacher of rhetoric before he became a Christian; moreover his reduction of the Trinity to a Neoplatonic triad was at worst a failed experiment in the defence of a catholic doctrine. Priscillian's career, on the other hand, ought to have equipped him to know the difference between a catholic and a gnostic, and his extant works were designed to counteract charges laid against him by the guardians of orthodoxy. Yet he himself makes at least one simple error in citation, when he has God say to Jacob rather than Moses, "I shall make thee a god to Pharaoh" ${ }^{55}$ If there were no other echo of the Gospel of Truth in his work than the aphorism "the name of the Father is the Son", we might guess that the author of the treatise On the Trinity had fallen prey to a similar lapse of memory. This conjecture will not suffice, however, if his teaching on the Trinity is leavened from first to last by the theology of the Valentinian text.

It might not be absurd to surmise that the author was himself a Valentinian, or if more properly a convert to the Priscillianists who had not renounced his earlier convictions. More circumspectly, we can propose that the author, or the circle of Prisicllianists to which he belonged, had added the Gospel of Truth to the miscellany of apocryphal texts defended by Priscillian in Tractate III. ${ }^{56}$ Both sects, after all, purported to be true Christians, and neither, so far as we know, possessed rigid articles of belief. If it be objected that he cites the canonical scriptures with more frequency than any of our Valentinian texts from Nag Hammadi, we should remember that ancient usage of the term "Valentinian" also covers Heracleon's exegesis of the Fourth Gospel and the Excerpts from Theodotus, which are denser in quotations from the New Testament than the writings of most catholics in the same era. ${ }^{57}$ Modern scholars have argued that the name was applied too liberally by the first heresiologists, but imperial legislators of the fourth century, placed the Valentiniani in close proximity to the followers of Priscillian in a list of sects who were not allowed to

\footnotetext{
${ }^{54}$ See further M. Tardieu, Recherches sur la formation de l'Apocalypse Zostrien et les sources de Marius Victorinus ((Bures-sur-Yvette, 1996); for criticism see L. Abramowski, “Audi ut dico: Literarische Beobachtungen und chronologische Erwägungen zu Marius Victorinus und den 'platonisierenden' Nag Hammadi Traktaten", ZKG 117 (2007), 145-168.

${ }^{55}$ Tractate III, line 47 at Conti (2010), 84. Cf. Exodus 7.1.

${ }^{56}$ A.S. Jacobs, "The Disorder of Books: Priscillian's Canonical Defense of Apocrypha", Harvard Theological Review 93 (2000), 135-159 adduces this text as evidence that the canon was not so rigid in the fourth century as is commonly supposed. See also V. Burrus, “Canonical References to Extra-Canonical 'Texts': Priscillian's Defense of the Apocrypha", in D.J. Lull (ed), Society of Biblical Literature Seminar Papers (Atlanta: SBL, 1990), 60-67.

${ }^{57}$ For discussion of Heracleon and his relation to Valentinus in the light of recent scholarship, see E. Thomassen, "Heracleon" (ed.), in T. Rasimus, The Legacy of John: Second Century Reception of the Fourth Gospel (Leiden: Brill, 2010), 173-2010.
} 
build churches in any city. ${ }^{58}$ Hostilities between the Valentinians and those were known as Arians could become turbulent, as we learn from the Emperor Julian's letter of reprimand to both parties. ${ }^{59}$ In our present state of knowledge, it would be as rash to dismiss the Valentinians as a construct as to give them the character of a separate school.

Epiphanius says that in his own time they called themselves "gnostics", ${ }^{60}$ though their use of this adjective as a self-description or self-designation is not attested in earlier times, when it was customary to speak of Valentinians and Gnostics as two heads of a burgeoning hydra. If they now professed to be "gnostics", they may also have styled themselves "catholics", since adherence to the catholic church did not prevent Evagrius from styling himself a gnostic or Tertullian from speaking with disdain of his "psychic" neighbours. ${ }^{61}$ Indeed, the fiery African (who was not ashamed to make use of Valentinian terminology ${ }^{62}$ ) might have found this work On the Trinity more to his taste than those of the Nicenes who maintained that the Son is equal to the Father and eternally distinct from him as a person..$^{63}$ It is possible that the word "catholic" is used with belligerent irony, for the treatise was composed at a time when the meaning of this term was a subject of controversy in Spain; ${ }^{64}$ on the other hand, it may be that the author was unaware of the shifts that catholic teaching had undergone since the epoch of Tertullian. He is not in fact propounding any doctrines which are plainly forbidden in the Nicene Creed, and this in any case was not the formula to which Latin writers turned in the late fourth century when they were drawing up a summary of the faith without polemical intent. ${ }^{65}$ The Valentinians, of course, were always heretics in the eyes of the episcopate, but they were not the only sect who found that the tenets which they held in common with catholics of one period were added to the inventory of their errors in the next.

\footnotetext{
${ }^{58}$ Codex Theodosianus 16.5.65.2, dated to May 30428.

59 Julian, letter 43 in the edition of F. C. Hetlein (Leipzig: Teubner, 1875), vol. 1, p. 573. Thomassen, Spiritual Seed, 506-508 cites Julian's letter and Ambrose, Epp. extra coll. 1 as evidence of the late survival of Valentinianism, but makes no reference to the text which is the subject of this paper.

${ }^{60}$ Panarion 31.1.5 and 31.7.8.

${ }^{61}$ See Tertullian, On Fasting 1.1; J. Konstantinovsky, Evagrius: The Making of a Christian Gnostic (Farnham., Surrey: Ashgate, 2009).

62 Tertullian, Against Praxeas 8.1

${ }^{63}$ In fact the "appeal to the fathers", which becomes common for the first time in the Theodosian era, was often made by authors who "were not strictly orthodox by later standards": M. Vessey, "The Forging of Orthodoxy in Latin Christian Literature: A Case Study", Journal of Early Christian Studies 4 (1996), $495-513$ at 499.

${ }^{64}$ Pacianus of Barcelona, Letters 1.4 and 2.2, in Écrtis, ed, C. Granado (Paris: Cerf, 1995), 174 and 188.

${ }^{65}$ See Rufinus, De Symbolo Apostolorum; Augustine De Catechizandis Rudbius.
} 